\title{
Correction to: Preventive service utilization among low-income cancer survivors
}

\author{
Brenna E. Blackburn ${ }^{1,2} \cdot$ Miguel Marino $^{1,3} \cdot$ Teresa Schmidt $^{4} \cdot$ John Heintzman ${ }^{1,4} \cdot$ Brigit Hatch $^{1,4}$. Jennifer DeVoe ${ }^{1,4}$. \\ Laura Moreno $^{1}$ (D) Nathalie Huguet ${ }^{1}$
}

Published online: 21 September 2021

๑) Springer Science+Business Media, LLC, part of Springer Nature 2021

\section{Correction to: Journal of Cancer Survivorship https://doi.org/10.1007/s11764-021-01095-7}

The article "Preventive service utilization among lowincome cancer survivors," written by Brenna E. Blackburn, was originally published electronically on the publisher's Internet portal on 19 August 2021 without open access. With the author(s)' decision to opt for Open Choice the copyright of the article changed on 27 August 2021 to $\odot$ The Author(s) 2021 and the article is forthwith distributed under a Creative Commons Attribution.

Open Access This article is licensed under a Creative Commons Attribution 4.0 International License, which permits use, sharing, adaptation, distribution, and reproduction in any medium or format, as long as you give appropriate credit to the original author(s) and the source, provide a link to the Creative Commons licence, and indicate if changes were made. The images or other third-party material in this article are included in the article's Creative Commons licence, unless indicated otherwise in a credit line to the material. If material is not included in the article's Creative Commons licence and your intended use is not permitted by statutory regulation or exceeds the permitted use, you will need to obtain permission directly from the copyright holder. To view a copy of this licence, visit http://creativecommons.org/licenses/by/4.0/.

Publisher's note Springer Nature remains neutral with regard to jurisdictional claims in published maps and institutional affiliations.
The original article can be found online at https://doi.org/10.1007/ s11764-021-01095-7

Brenna E. Blackburn

Brenna.blackburn@utah.edu

1 Department of Family Medicine, Oregon Health \& Science University, 3181 Sam Jackson Park Road, Portland, OR, USA

2 Department of Family and Preventive Medicine, School of Medicine, University of Utah, 375 Chipeta Way, Salt Lake City, UT 84108, USA

3 Division of Biostatistics, School of Public Health, Oregon Health \& Science University - Portland State University, 3181 SW Sam Jackson Park Road, Portland, OR, USA

4 OCHIN, Inc., 1881 SW Naito Pkwy, Portland, OR, USA 